\title{
S100A4 mRNA expression level is a predictor of radioresistance of pancreatic cancer cells
}

\author{
SHINGO KOZONO $^{1}$, KENOKI OHUCHIDA ${ }^{1,2}$, TAKAO OHTSUKA $^{1}$, LIN CUI $^{1}$, DAIKI EGUCHI $^{1}$, \\ KENJI FUJIWARA $^{1}$, MING ZHAO ${ }^{1}$, KAZUHIRO MIZUMOTO ${ }^{1,3}$ and MASAO TANAKA ${ }^{1}$ \\ Departments of ${ }^{1}$ Surgery and Oncology, and ${ }^{2}$ Advanced Medical Initiatives, Graduate School of Medical Sciences, \\ Kyushu University; ${ }^{3}$ Kyushu University Hospital Cancer Center, Fukuoka, Japan
}

Received February 26, 2013; Accepted April 23, 2013

DOI: $10.3892 /$ or.2013.2636

\begin{abstract}
Improving poor outcomes in patients with pancreatic cancer requires a greater understanding of the biological mechanisms contributing to radioresistance. We, therefore, sought to identify genes involved in the radioresistance of pancreatic cancer cells. Two pancreatic cancer cell lines, CFPAC-1 and Capan-1, were repeatedly exposed to radiation, establishing two radioresistant cell lines. Gene expression profiling using cDNA microarrays was performed to identify genes responsible for radioresistance. The levels of expression of mRNAs encoded by selected genes and their correlation with radiation dose resulting in 50\% survival rate were analyzed in pancreatic cancer cell lines. The radiation dose resulting in a $50 \%$ survival rate was significantly higher in irradiated (IR) compared to parental CFPAC-1 cells $(8.31 \pm 0.85$ Gy vs. $2.14 \pm 0.04 \mathrm{~Gy}$, $\mathrm{P}<0.0001)$, but was lower in IR compared with parental Capan-1 cells (2.66 \pm 0.24 Gy vs. $2.25 \pm 0.03 \mathrm{~Gy}, \mathrm{P}=0.04)$. cDNA microarray analysis identified 4 genes, including S100 calcium binding protein A4 (S100A4), overexpressed and 23 genes underexpressed in the IR compared with the parental cell lines. The levels of S100A4 mRNA expression were correlated with radiation dose resulting in a 50\% survival rate (Pearson's test, $\left.\mathrm{R}^{2}=0.81, \mathrm{P}=0.0025\right)$. $\mathrm{S} 100 \mathrm{~A} 4 \mathrm{mRNA}$ expression may predict radioresistance of pancreatic cancer cells and may play an important role in the poor response of pancreatic cancer cells to radiation therapy.
\end{abstract}

\section{Introduction}

Pancreatic cancer is the fourth leading cause of cancerrelated mortality in Western countries and has the lowest survival rate of any solid tumor (1). Although patients with

Correspondence to: Dr Kazuhiro Mizumoto or Dr Kenoki Ohuchida, Department of Surgery and Oncology, Graduate School of Medical Sciences, Kyushu University, 3-1-1 Maidashi, Fukuoka 812-8582, Japan E-mail: mizumoto@med.kyushu-u.ac.jp

E-mail: kenoki@med.kyushu-u.ac.jp

Key words: S100 calcium binding protein A4, pancreatic cancer cell line, radiosensitivity, radioresistance, cDNA microarray pancreatic cancer are treated with comprehensive therapy, including surgery, chemotherapy and radiotherapy, their 5 -year survival rate is $<5 \%$ (2). Approximately $25-30 \%$ of these patients are initially diagnosed with locally advanced pancreatic cancer $(3,4)$. Although radiotherapy combined with chemotherapy is the recommended treatment strategy, the contribution of radiotherapy is unclear $(3,4)$. To improve the outcome of patients with pancreatic cancer, a greater understanding of the biological mechanisms that contribute to tumor refractoriness to radiotherapy is required. Moreover, identification of markers of radioresistance may contribute to the identification of agents to treat this fatal disease.

The cDNA microarray technique is a powerful tool for analyzing comprehensive gene expression in cells (5). To identify genes that contribute to resistance to radiation therapy, cDNA microarray analysis has compared radioresistant and radiosensitive cancer cells in various types of tumor, including uterine cervical, head and neck, colorectal, breast, esophageal, lung, hepatocellular and pancreatic cancer, as well as in malignant melanoma (6). Several genes identified by cDNA microarray analysis encode proteins involved in apoptosis, DNA repair, signal transduction, cell cycle and cell adhesion, as well as genes encoding growth factors and growth factor receptors (6). Although these genes may contribute to radioresistance, more information is required to evaluate the mechanism underlying resistance to radiotherapy in these tumor types.

We therefore exposed pancreatic cancer cell lines to radiation and compared comprehensive gene expression of irradiated (IR) and parental cells using cDNA microarray technique. We selected promising genes and evaluated their contribution to the radioresistance of pancreatic cancer cell lines.

\section{Materials and methods}

Cell lines. Three human pancreatic cancer cell lines, SUIT-2, PANC-1 and MIA PaCa-2, were obtained from the Japanese Cancer Resource Bank (Tokyo, Japan) and three other human pancreatic cancer cell lines, Capan-1, Capan-2 and CFPAC-1, were obtained from the American Type Culture Collection (Manassas, VA, USA); all 6 cell lines bear mutant p53 (7-9). The cells were maintained as previously described (10). 
Irradiation of pancreatic cancer cell lines. Two pancreatic cancer cell lines, Capan-1 and CFPAC-1, were repeatedly exposed to 2 Gy X-ray irradiation for a total dose of $10 \mathrm{~Gy}$, followed by irradiation with $5 \mathrm{~Gy}$ to a total dose of $60 \mathrm{~Gy}$, with 14-day intervals between treatments. IR cells were cultured in Dulbecco's modified Eagle's medium (DMEM) supplemented with $10 \%$ FBS.

Evaluation of cell rediosensitivity. Radiosensitivity was assessed by colony formation assays. All pancreatic cell lines were plated at $1 \times 10^{4}$ cells/well in 6-well plates (Thermo Scientific, Rockford, IL, USA) for $24 \mathrm{~h}$, followed by exchange of conditioned medium. The cells were irradiated at $0,1,2,3$, 5, 7, 8 and 10 Gy and incubated for 7 days without exchange of medium. The plates were fixed in $70 \%$ ethanol and stained with $0.1 \%$ crystal violet and colonies were counted using a ChemiDoc XRS System (Bio-Rad Laboratories). Survival rates were determined by comparing the number of colonies at each radiation dose with that in unirradiated ( $0 \mathrm{~Gy})$ cells. All survival curves represent the combined results of three independent experiments.

Microarray analysis. Microarray analyses were performed using IR-Capan-1 and IR-CFPAC-1 cells and their respective parental cells. The qualities of the RNA samples were evaluated using a 2100 Bioanalyzer (Agilent Technologies, Waldbronn, Germany) as described (11). Analyses were performed using a HumanWG-6 Expression BeadChip and the results were analyzed using BeadStudio software version 3.2.3 (both from Illumina, San Diego, CA, USA).

Real-time $q R T-P C R$. Total RNA was extracted from pellets of cultured cells using a High Pure RNA Kit (Roche Diagnostics, Mannheim, Germany) and treated with DNase I (Roche Diagnostics), according to the manufacturer's instructions. Specific primers for S100 calcium binding protein A4 (S100A4) (forward, 5'-atcgccatgatgtgtaccga-3'; reverse, 5'-cccaaccacatcagagg agt-3') and $\beta$-actin (forward, 5'-tgagcgcggctacagctt-3'; reverse, 5'-tccttaatgtcacgcacgattt-3') RNAs were designed using primer 3 , with BLAST searches performed to ensure the specificity of each primer. The extracts were analyzed by qRT-PCR using a QuantiTect SYBR-Green RT-PCR Kit (Qiagen, Tokyo, Japan) and a Chrom4 Real-Time PCR Detection System (Bio-Rad Laboratories, Hercules, CA, USA). Each reaction mixture was initially incubated at $50^{\circ} \mathrm{C}$ for $30 \mathrm{~min}$ to allow reverse transcription, in which first-strand cDNA was synthesized by priming the total RNA with the same gene-specific primer (reverse). PCR was initiated by incubation at $95^{\circ} \mathrm{C}$ for $15 \mathrm{~min}$ to activate the polymerase, followed by 40 cycles of $94^{\circ} \mathrm{C}$ for $15 \mathrm{sec}, 58^{\circ} \mathrm{C}$ for $30 \mathrm{sec}$ and $72^{\circ} \mathrm{C}$ for $30 \mathrm{sec}$. Each of these primer sets produced a single prominent band of the expected size after electrophoresis. Each sample was analyzed twice and any samples showing $>10 \%$ deviation in qRT-PCR results were tested a third time. The level of mRNA expression in each sample was calculated by reference to a standard curve generated using total RNA from the SUIT-2 human pancreatic cancer cell line. The expression of S100A4 mRNA was normalized relative to the expression of $\beta$-actin mRNA in the same sample.
Western blotting. Cell proteins were extracted by PRO-PREP (iNtRON Biotechnology, Seongnam, Korea) according to the manufacturer's instructions. Cell lysates containing $15 \mu \mathrm{g}$ protein were fractionated on $12 \%$ sodium dodecyl sulfatepolyacrylamide gel electrophoresis gels and transferred to polyvinylidene difluoride membranes (Millipore, Billerica, MA, USA). Each membrane was incubated overnight at $4^{\circ} \mathrm{C}$ with anti-S100A4 (1:500; DAKO, Glostrup, Denmark) or anti- $\beta$-actin (05-829, 1:1,000; Millipore) and subsequently with secondary antibodies conjugated to horseradish peroxidase (Santa Cruz Biotechnology, Inc.). Immunoblots were detected by enhanced chemiluminescence with a Chemi Doc XRS System.

Cell proliferation assay. Cell proliferation was evaluated by measuring the fluorescence intensity of propidium iodide (PI), as previously described (12). Briefly, cells were seeded at $2 \times 10^{4}$ cells/well in 24-well tissue culture plates (Becton Dickinson Labware, Bedford, MA, USA) and cultured in DMEM containing 10\% FBS for $24 \mathrm{~h}$. Following confirmation of cellular adhesion to the plates, the medium was replaced and $30 \mu \mathrm{M}$ PI and $600 \mu \mathrm{M}$ digitonin were added to each well to label the nuclei with PI. The fluorescence intensity, corresponding to the total cell number, was measured using an Infinite ${ }^{\circledR} 200$ PRO multiwell plate reader (TECAN, Mannedorf, Switzerland) with excitation and emission wavelengths of 530 and $645 \mathrm{~nm}$, respectively. A separate well containing the same medium was used to provide a baseline PI signal as a control. The difference in intensity between each sample well and the control well was calculated. Cell proliferation was defined relative to the number of cells counted immediately after exchanging the medium. All experiments were performed in triplicate wells and were repeated at least three times.

Statistical analysis. All statistical analyses were performed using JMP 8.0.1 software (SAS Institute, Inc., Cary, NC, USA). Pearson's test was measured to evaluate the relationships between S100A4 mRNA expression and radiation dose associated with $50 \%$ cell survival, S100A4 mRNA expression and relative proliferation of pancreatic cancer cells and relative proliferation of pancreatic cancer cells and radiation dose associate with $50 \%$ cell survival. All values are expressed as means \pm standard deviation. $\mathrm{P}<0.05$ was considered to indicate a statistically significant difference.

\section{Results}

Evaluation of radiosensitivity of IR-CFPAC-1 and Capan-1 cells. Two pancreatic cancer cell lines, CFPAC-1 and Capan-1, were exposed to fractionated irradiation until the total irradiation dose was 60 Gy. Radiosensitivity was evaluated by the colony formation assay. IR-CFPAC-1 cells showed significantly greater radioresistance compared to parental cells. The radiation dose resulting in a 50\% survival rate was significantly higher in IR compared to parental CFPAC-1 cells (8.31 \pm 0.85 Gy vs. 2.14 \pm 0.04 Gy, P<0.0001; Fig. 1A and B), but the difference was less pronounced in IR compared to parental Capan-1 cells $(2.66 \pm 0.24$ Gy vs. $2.25 \pm 0.03 \mathrm{~Gy}$, $\mathrm{P}=0.04)$. 
Table I. Average ratios of expression of upregulated genes in radioresistant compared with parental cells (fold-change $>2$ ).

\begin{tabular}{|c|c|c|c|c|c|}
\hline \multirow[b]{2}{*}{ Rank } & \multirow[b]{2}{*}{ Gene name } & \multicolumn{2}{|c|}{ Fold-change } & \multirow[b]{2}{*}{ Function } & \multirow[b]{2}{*}{ Sequence code } \\
\hline & & CFPAC-1 & Capan-1 & & \\
\hline 1 & $\begin{array}{l}\text { S100 calcium binding } \\
\text { protein A4 (S100A4) }\end{array}$ & 138.3 & 8.5 & $\begin{array}{l}\text { Regulation of a number of cellular } \\
\text { processes such as cell cycle } \\
\text { progression and differentiation }\end{array}$ & NM_019554.2 \\
\hline 2 & $\begin{array}{l}\text { Transmembrane protein } 158 \\
\text { (TMEM158) }\end{array}$ & 18.1 & 3.2 & $\begin{array}{l}\text { Upregulated in response to activation } \\
\text { of the Ras pathway, but not under other } \\
\text { conditions that induce senescence }\end{array}$ & NM_015444.2 \\
\hline 3 & Caveolin 2 (CAV2) & 16.3 & 2.4 & $\begin{array}{l}\text { Signal transduction, lipid metabolism, } \\
\text { cellular growth control and apoptosis }\end{array}$ & NM_001233.3 \\
\hline 4 & $\begin{array}{l}\text { Phosphoprotein enriched in } \\
\text { astrocytes } 15 \text { (PEA15) }\end{array}$ & 5.5 & 2.1 & Regulation of apoptosis & NM_003768.2 \\
\hline
\end{tabular}
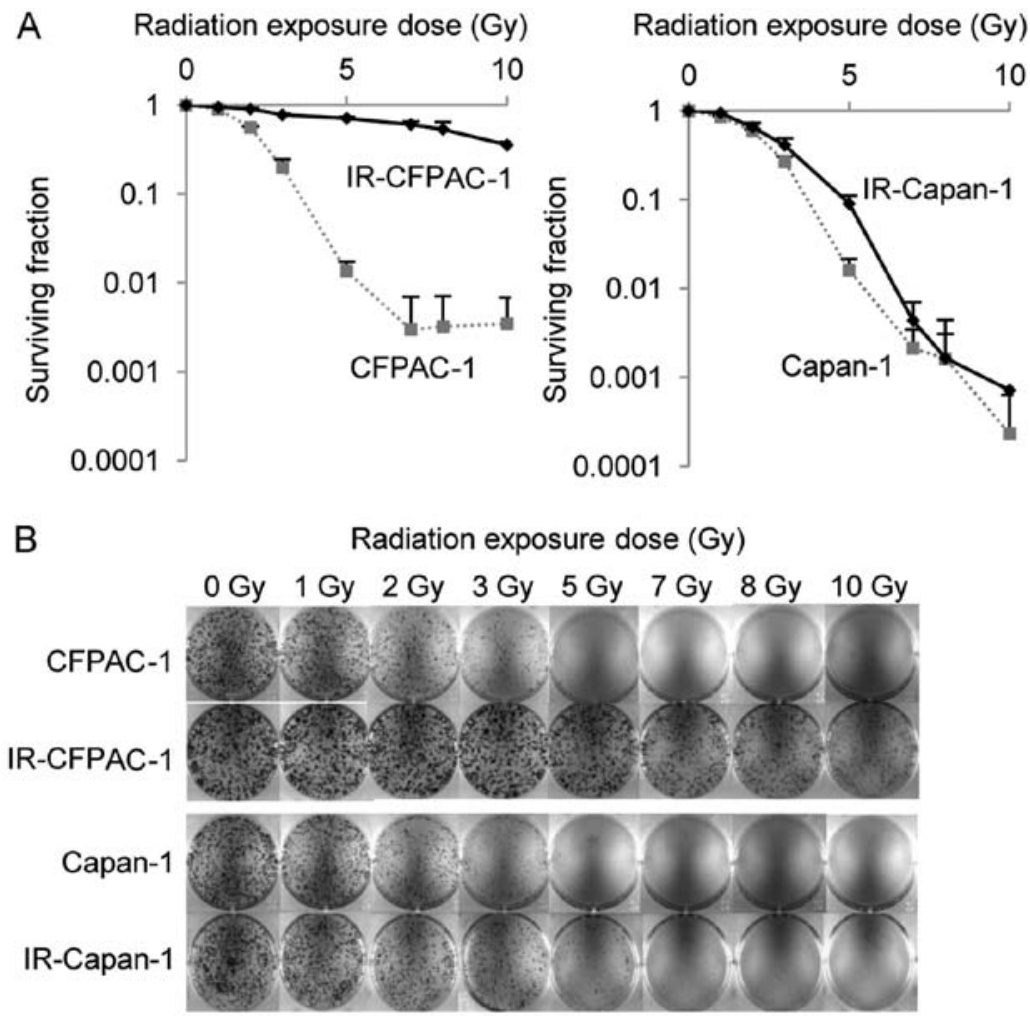

Figure 1. Radiosensitivity of parent and irradiated (IR) CFPAC-1 and Capan-1 cells. (A) Radiosensitivity was evaluated by the colony formation assay. IR-CFPAC-1 showed significantly greater radioresistance than parental cells, with radiation doses associated with $50 \%$ survival rates of $8.31 \pm 0.85$ and $2.14 \pm 0.04 \mathrm{~Gy}$, respectively $(\mathrm{P}<0.0001)$. Irradiation had a reduced effect on Capan-1 cells, with radiation doses associated with $50 \%$ survival rates of IR-Capan-1 and Capan-1 cells of 2.66 \pm 0.24 and $2.25 \pm 0.03 \mathrm{~Gy}$, respectively $(\mathrm{P}=0.0426)$. (B) Representative images of colonies formed by each cell line following irradiation.

mRNA expression profiling of IR and parental pancreatic cancer cell lines. We performed global microarray expression analysis of 48,803 genes to compare two IR pancreatic cancer cell lines (IR-CFPAC-1 and IR-Capan-1) with those of their respective parental cell lines (CFPAC-1 and Capan-1). A difference was defined as significant if the ratio of expression between IR and parental cells was $>2$ - or $<0.33$-fold. We found that 4 genes were upregulated (Table I) and 23 were downregulated (Table II) in IR compared with parental cells. One of the overexpressed genes was S100A4, the increased expression of which has been associated with radiation exposure in lung cancer cell lines (13). Of the 23 downregulated genes, none of which has been reported to be associated with radioresistance, 7 were potentially involved in apoptosis, cell attachment and inhibition of cell proliferation and tumor suppression.

S100A4 expression in cultured pancreatic cancer cell lines. We investigated the levels of expression of S100A4 mRNA in cultures of 6 unirradiated and 2 IR pancreatic cancer cell lines. S100A4 mRNA expression was higher in both IR cell lines 
Table II. Identification of the 23 genes downregulated in radioresistant CFPAC-1 and Capan-1 cells compared with their respective parental cells (fold-change $<0.33$ ).

\begin{tabular}{|c|c|c|c|c|c|}
\hline \multirow[b]{2}{*}{ Rank } & \multirow[b]{2}{*}{ Gene name } & \multicolumn{2}{|c|}{ Fold-change } & \multirow[b]{2}{*}{ Function } & \multirow[b]{2}{*}{ Sequence code } \\
\hline & & CFPAC-1 & Capan-1 & & \\
\hline 1 & Inhibitor of DNA binding 3 (ID3) & 0.02 & 0.27 & $\begin{array}{l}\text { Negative regulation of } \\
\text { transcription factor activity }\end{array}$ & NM_002167.2 \\
\hline 2 & $\begin{array}{l}\text { Odontogenic, ameloblast associated } \\
\text { (ODAM) }\end{array}$ & 0.03 & 0.15 & Odontogenesis & NM_017855.3 \\
\hline 3 & $\begin{array}{l}\text { Rho-related BTB domain } \\
\text { containing } 3 \text { (RHOBTB3) }\end{array}$ & 0.03 & 0.19 & $\begin{array}{l}\text { Small GTPase-mediated signal } \\
\text { transduction and the organization of } \\
\text { the actin filament system }\end{array}$ & NM_014899.3 \\
\hline 4 & $\begin{array}{l}\text { Eukaryotic translation elongation } \\
\text { factor } 1 \alpha 2(\mathrm{EEF} 1 \mathrm{~A} 2)\end{array}$ & 0.04 & 0.07 & $\begin{array}{l}\text { Protein biosynthesis, } \\
\text { translational elongation }\end{array}$ & NM_001958.2 \\
\hline 5 & $\begin{array}{l}\text { Naked cuticle homolog } 2 \\
\text { (Drosophila) (NKD2) }\end{array}$ & 0.07 & 0.30 & $\begin{array}{l}\text { Negative regulator of the Wnt } \\
\text { in the mouse }\end{array}$ & NM_033120.2 \\
\hline 6 & $\begin{array}{l}\text { Quinolinate phosphoribosyl- } \\
\text { transferase (QPRT) }\end{array}$ & 0.08 & 0.04 & $\begin{array}{l}\text { Generation of precursor metabolites and } \\
\text { energy, NAD biosynthesis, synaptic } \\
\text { transmission }\end{array}$ & NM_014298.3 \\
\hline 7 & $\begin{array}{l}\text { Imprinted maternally expressed } \\
\text { transcript (H19) }\end{array}$ & 0.08 & 0.05 & $\begin{array}{l}\text { Non-coding RNA and functions as a } \\
\text { tumor suppressor }\end{array}$ & NR_002196.1 \\
\hline 8 & $\begin{array}{l}\text { Homo sapiens laminin, } \alpha 2 \\
\text { (LAMA2) }\end{array}$ & 0.10 & 0.09 & $\begin{array}{l}\text { Regulation of embryonic development, } \\
\text { muscle development, cell migration } \\
\text { and adhesion }\end{array}$ & NM_001079823.1 \\
\hline 9 & Vasorin (VASN) & 0.13 & 0.28 & $\begin{array}{l}\text { Vasorin was reported to contribute to } \\
\text { neointimal formation after vascular injury }\end{array}$ & NM_138440.2 \\
\hline 10 & $\begin{array}{l}\text { AT rich interactive domain 5B } \\
\text { (MRF1-like) (ARID5B) }\end{array}$ & 0.15 & 0.32 & Negative regulation of transcription & NM_032199.1 \\
\hline 11 & $\begin{array}{l}\text { G protein-coupled receptor } 56 \\
\text { (GPR56) }\end{array}$ & 0.15 & 0.26 & $\begin{array}{l}\text { Cell adhesion, cell-cell signaling, } \\
\text { signal transduction }\end{array}$ & NM_005682.4 \\
\hline 12 & Vaccinia related kinase 2 (VRK2) & 0.17 & 0.33 & Protein amino acid phosphorylation & NM_006296.3 \\
\hline 13 & $\begin{array}{l}\text { Similar to CG14853-PB } \\
\text { (LOC285141) }\end{array}$ & 0.17 & 0.26 & & XM_939141.1 \\
\hline 14 & Growth arrest-specific 6 (GAS6) & 0.17 & 0.32 & Cell proliferation & NM_000820.1 \\
\hline 15 & $\begin{array}{l}\text { T-box } 3 \text { (ulnar mammary } \\
\text { syndrome) (TBX3) }\end{array}$ & 0.17 & 0.29 & $\begin{array}{l}\text { Morphogenesis, skeletal development, } \\
\text { regulation of transcription from RNA } \\
\text { polymerase II promoter }\end{array}$ & NM_016569.3 \\
\hline 16 & $\begin{array}{l}\text { Collagen, type VII, } \alpha 1 \\
\text { (COL7A1) }\end{array}$ & 0.21 & 0.20 & $\begin{array}{l}\text { Cell adhesion, phosphate transport, } \\
\text { epidermis development }\end{array}$ & NM_000094.2 \\
\hline 17 & $\begin{array}{l}\text { Cystic fibrosis transmembrane } \\
\text { conductance regulator (CFTR) }\end{array}$ & 0.21 & 0.20 & $\begin{array}{l}\text { Ion transport, respiratory gaseous } \\
\text { exchange }\end{array}$ & NM_000492.3 \\
\hline 18 & Synaptotagmin-like 2 (SYTL2) & 0.22 & 0.15 & $\begin{array}{l}\text { Vesicle-mediated transport, intracellular } \\
\text { protein transport }\end{array}$ & NM_032943.2 \\
\hline 19 & POM and ZP3 fusion (POMZP3) & 0.25 & 0.18 & & NM_152992.2 \\
\hline 20 & Prominin 1 (PROM1) & 0.28 & 0.06 & Visual perception & NM_006017.1 \\
\hline 21 & $\begin{array}{l}\text { Suppressor of cytokine signaling } 2 \\
\text { (SOCS } 2)\end{array}$ & 0.32 & 0.19 & $\begin{array}{l}\text { JAK-STAT cascade, negative regulation } \\
\text { of signal transduction, anti-apoptosis, } \\
\text { regulation of cell growth }\end{array}$ & NM_003877.3 \\
\hline 22 & $\begin{array}{l}\text { Shroom family member } 4 \\
\text { (SHROOM4) }\end{array}$ & 0.32 & 0.16 & To play a role in cytoskeletal architecture & NM_020717.2 \\
\hline 23 & Angiopoietin 1 (ANGPT1) & 0.33 & 0.16 & $\begin{array}{l}\text { Angiogenesis, cell differentiation, } \\
\text { signal transduction }\end{array}$ & NM_001146.3 \\
\hline
\end{tabular}


Table III. Radiation dose associated with 50\% survival rates of 6 pancreatic cancer cell lines and IR cell lines.

\begin{tabular}{lc}
\hline Cell line & Radiation dose (Gy) \\
\hline IR-CFPAC-1 & $8.31 \pm 0.85$ \\
SUIT-2 & $7.80 \pm 1.07$ \\
PANC-1 & $5.94 \pm 0.66$ \\
MIA PaCa-2 & $4.90 \pm 0.64$ \\
IR-Capan-1 & $2.66 \pm 0.24$ \\
Capan-1 & $2.25 \pm 0.03$ \\
CFPAC-1 & $2.14 \pm 0.04$ \\
Capan-2 & $2.04 \pm 0.32$ \\
\hline
\end{tabular}

IR, irradiated.

compared to the unirradiated cells, a finding consistent with our microarray data (Fig. 2A). Compared with their respective parental cell lines, the levels of expression of S100A4 mRNA were 54-fold higher in IR-CFPAC-1 compared to CFPAC-1 cells and 5.0-fold higher in IR-Capan-1 compared to Capan-1 cells, with both differences being statistically significant. The level of S100A4 protein was significantly higher in IR-CFPAC-1 compared to IR-Capan-1 cells, the latter of which, as well as parental Capan-1 cells, expressed no S100A4 protein (Fig. 2B). S100A4 protein and mRNA expression were closely correlated in these cell lines. These findings suggest that the difference in radiosensitivity between IR-CFPAC-1 and IR-Capan-1 cells may be due to differences in S100A4 expression.

S100A4 mRNA expression is significantly correlated with radiation dose associated with $50 \%$ survival. To analyze the radiosensitivity of pancreatic cell lines, we calculated the radiation dose associated with 50\% survival rates (Fig. 3A and B, Table III). We found that S100A4 mRNA expression was significantly correlated with this radiation dose (Pearson's test, $\mathrm{R}^{2}=0.81, \mathrm{P}=0.0025$ ) (Fig. 4A) but not with cell proliferation (Pearson's test, $\mathrm{R}^{2}=0.04, \mathrm{P}=0.62$ ) (Fig. $4 \mathrm{~B}$ ). In addition, radiation dose associated with $50 \%$ cell survival was not correlated with cell proliferation (Pearson's test, $\mathrm{R}^{2}=0.10$, $\mathrm{P}=0.45$ ) (Fig. 4C). These findings indicate that S100A4 mRNA expression was closely associated with the radioresistance of pancreatic cancer cell lines.

\section{Discussion}

Radiotherapy is among the key treatment strategies for patients with various types of cancer. Some patients benefit from radiotherapy, whereas others do not. In particular, the survival benefits of radiotherapy in patients with pancreatic cancer remain unclear $(3,4)$. The molecular mechanisms associated with tumor response to radiotherapy have been assessed in several types of tumor by cDNA microarray analysis, comparing radiosensitive and radioresistant cancer. These include esophageal cancer (14), head and neck cancer (15), cervical cancer (16-18), breast cancer (19), pancreatic cancer (6), glioblastoma (20), hepatocellular carcinoma (21), malignant melanoma (22) and lung cancer $(23,24)$. Most of the

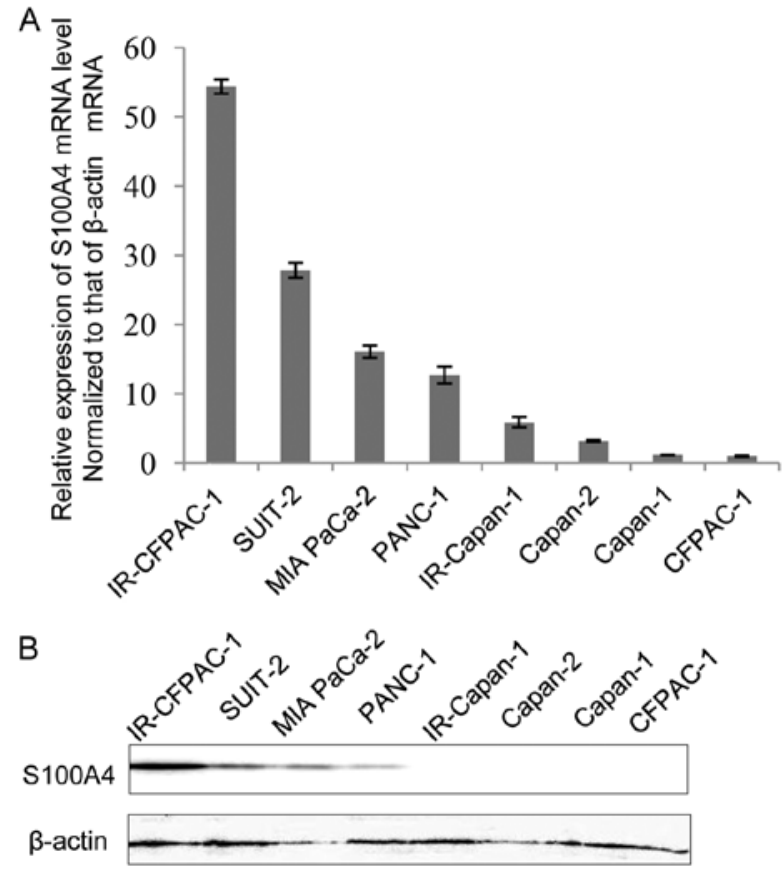

Figure 2.S100A4 expression in 6 pancreatic cancer cell lines and 2 irradiated (IR) cell lines. (A) S100A4 mRNA expression was analyzed by qRT-PCR and normalized relative to $\beta$-actin mRNA. S100A4 mRNA expression levels were 54.4- and 5.0-fold higher in IR-CFPAC-1 and IR-Capan-1 cells, respectively, compared to their respective parental cell lines. (B) S100A4 protein level was significantly higher in IR-CFPAC-1 compared to CFPAC-1 cells, whereas S100A4 protein was not detected in IR-Capan-1 or Capan-1 cells.

genes identified in these cDNA arrays were associated with DNA-repair, apoptosis, growth factors, signal transduction, cell cycle and cell adhesion. Similarly, our cDNA microarray analysis also identified several genes involved in these signaling pathways. However, none of these genes has been identified in previous cDNA microarrays and some tumor types have few genes in common that are up- or downregulated. Thus, the mechanism of radioresistance in cancer cells is very complicated.

In analyzing pancreatic cancer cells, we found that S100A4 mRNA expression was markedly upregulated following irradiation, with the degree of upregulation differing significantly in strongly radioresistant IR-CFPAC-1 cells and weakly radioresistant IR-Capan-1 cells. Irradiation of lung cancer cell lines has been reported to increase the expression of S100A4 and S100A6 proteins (13). To our knowledge, our study is the first to show that the level of expression of S100A4 mRNA is directly correlated with radioresistance of pancreatic cancer cells.

S100A4 is a member of the S100 family of calcium binding proteins, which are characterized by two distinct EF-hand structural motifs $(25,26)$. S100A4 is overexpressed in a number of solid tumors, including breast, esophageal, gastric, colorectal and pancreatic cancer and is associated with poor prognosis in patients with these types of cancer $(27,28)$. S100A4 has been reported to promote cell motility and invasion in cancer and to be associated with tumor metastasis $(29,30)$. Although we observed an association between S100A4 expression and radioresistance of pancreatic cancer cell lines, the mechanism by which S100A4 induces radioresistance remains unclear. 
A



B



Figure 3. Radiosensitivity of pancreatic cancer cell lines. (A) Radiation cell survival curves of 6 pancreatic cancer cell lines and 2 irradiated (IR) cell lines. (B) Representative images of colonies formed by these cell lines following irradiation.


Figure 4. Correlation among S100A4 mRNA expression level, radiation dose associated with 50\% survival rate and relative proliferation in 6 pancreatic cancer cell lines and 2 irradiated (IR) cell lines. (A) Significant correlation between S100A4 mRNA expression level and 50\% radiation dose (Pearson's test, $\mathrm{R}^{2}=0.81$, $\mathrm{P}=0.0025$ ). (B) No significant correlation between $\mathrm{S} 100 \mathrm{~A} 4 \mathrm{mRNA}$ expression level and relative proliferation (Pearson's test, $\left.\mathrm{R}^{2}=0.04, \mathrm{P}=0.64\right)$. (C) No significant correlation between relative proliferation and $50 \%$ radiation dose (Pearson's test, $\mathrm{R}^{2}=0.10, \mathrm{P}=0.45$ ).

Wild-type p53 has been shown to play a crucial role in cellular responses to radiation-induced DNA damage through cell cycle arrest, apoptosis and DNA repair $(31,32)$. By contrast, mutant p53 has been shown to be involved in resistance to radiotherapy (33-36) and to have oncogenic properties by inducing the expression of sets of genes that activate cell proliferation, cell survival and angiogenesis (35). S100A4 has been reported to interact with wild-type p53 through the
C-terminal domain of the latter and may regulate $\mathrm{p} 53$ function, inducing cell apoptosis (37). Moreover, S100A4 may interact with mutant p53 (37). Activation of c-myc gene expression by mutant $\mathrm{p} 53$ has been reported to require the $\mathrm{C}$-terminal domain of the latter (38). The pancreatic cancer cells utilized in this study contain mutant p53 (7-9). These findings suggest that upregulation of S100A4 may increase its opportunities to interact with mutant $\mathrm{p} 53$, enhancing resistance to radiation. 
The NF-кB pathway has been reported to play an important role in the development of resistance to radiotherapy (39-41). Inhibition of the $\mathrm{NF}-\kappa \mathrm{B}$ pathway decreased resistance to radiotherapy. Moreover, release of S100A4 into the extracellular space has been found to activate the $\mathrm{NF}-\kappa \mathrm{B}$ pathway and induce specific gene transcription (42). We have shown here that higher expression of S100A4 was directly correlated with stronger radioresistance of pancreatic cancer cell lines. These findings suggest that upregulation of S100A4 expression may contribute to the activation of the $\mathrm{NF}-\kappa \mathrm{B}$ pathway more strongly in pancreatic cancer cells, leading to a sequential increase in radioresistance via the transcription of genes associated with radioresistance. Taken together, these findings indicate that S100A4 increases radioresistance by interacting with transcription factors that induce radioresistance. Further investigations of the mechanisms underlying these interactions are required.

In summary, we showed that S100A4 expression in pancreatic cancer cell lines was augmented by continuous irradiation and that assaying S100A4 mRNA expression could predict the radioresistance of pancreatic cancer cell lines. Based on these findings, we conclude that S100A4 is involved in the radioresistance of pancreatic cancer cell lines and may be involved in the mechanism by which pancreatic cancer acquires radioresistance. Treatment with agents targeting S100A4, along with radiation, may improve the prognosis of patients with pancreatic cancer undergoing radiotherapy.

\section{Acknowledgements}

This study was supported in part by the Ministry of Education, Culture, Sports, Science and Technology of Japan (MEXT) (MEXT KAKENHI Grants 23390327, 24659613, 24390319, 23659654, 24390318 and 23659655). The authors thank Emiko Manabe, Miyuki Omori and Makiko Masuda (Department of Surgery and Oncology, Kyushu University) for their technical assistance, and the Research Support Center, Graduate School of Medical Sciences, Kyushu University, for the technical support.

\section{References}

1. Hariharan D, Saied A and Kocher HM: Analysis of mortality rates for pancreatic cancer across the world. HPB (Oxford) 10 : 58-62, 2008.

2. Siegel R, Ward E, Brawley O and Jemal A: Cancer statistics, 2011: the impact of eliminating socioeconomic and racial disparities on premature cancer deaths. CA Cancer J Clin 61: 212-236, 2011

3. Johung K, Saif MW and Chang BW: Treatment of locally advanced pancreatic cancer: the role of radiation therapy. Int $\mathrm{J}$ Radiat Oncol Biol Phys 82: 508-518, 2012.

4. Wang F and Kumar P: The role of radiotherapy in management of pancreatic cancer. J Gastrointest Oncol 2: 157-167, 2011

5. Golub TR, Slonim DK, Tamayo P, et al: Molecular classification of cancer: class discovery and class prediction by gene expression monitoring. Science 286: 531-537, 1999.

6. Ogawa K, Utsunomiya T, Mimori K, et al: Differential gene expression profiles of radioresistant pancreatic cancer cell lines established by fractionated irradiation. Int J Oncol 28: 705-713, 2006.

7. Moore PS, Sipos B, Orlandini S, et al: Genetic profile of 22 pancreatic carcinoma cell lines. Analysis of K-ras, p53, p16 and DPC4/Smad4. Virchows Arch 439: 798-802, 2001.

8. Gardner-Thorpe J, Ito H, Ashley SW and Whang EE: Differential display of expressed genes in pancreatic cancer cells. Biochem Biophys Res Commun 293: 391-395, 2002.
9. Gupta S, Sathishkumar S and Ahmed MM: Influence of cell cycle checkpoints and p53 function on the toxicity of temozolomide in human pancreatic cancer cells. Pancreatology 10: 565-579, 2010.

10. Ohuchida K, Mizumoto K, Murakami M, et al: Radiation to stromal fibroblasts increases invasiveness of pancreatic cancer cells through tumor-stromal interactions. Cancer Res 64: 3215-3222, 2004.

11. Antonov J, Goldstein DR, Oberli A, et al: Reliable gene expression measurements from degraded RNA by quantitative real-time PCR depend on short amplicons and a proper normalization. Lab Invest 85: 1040-1050, 2005.

12. Zhang L, Mizumoto K, Sato N, et al: Quantitative determination of apoptotic death in cultured human pancreatic cancer cells by propidium iodide and digitonin. Cancer Lett 142: 129-137, 1999.

13. Orre LM, Pernemalm M, Lengqvist J, Lewensohn R and Lehtiö J: Up-regulation, modification, and translocation of S100A6 induced by exposure to ionizing radiation revealed by proteomics profiling. Mol Cell Proteomics 6: 2122-2131, 2007.

14. Fukuda K, Sakakura C, Miyagawa K, et al: Differential gene expression profiles of radioresistant oesophageal cancer cell lines established by continuous fractionated irradiation. Br J Cancer 91: 1543-1550, 2004.

15. Hanna E, Shrieve DC, Ratanatharathorn V, et al: A novel alternative approach for prediction of radiation response of squamous cell carcinoma of head and neck. Cancer Res 61: 2376-2380, 2001.

16. Harima Y, Togashi A, Horikoshi K, et al: Prediction of outcome of advanced cervical cancer to thermoradiotherapy according to expression profiles of 35 genes selected by cDNA microarray analysis. Int J Radiat Oncol Biol Phys 60: 237-248, 2004.

17. Tewari D, Monk BJ, Al-Ghazi MS, et al: Gene expression profiling of in vitro radiation resistance in cervical carcinoma: a feasibility study. Gynecol Oncol 99: 84-91, 2005.

18. Wong YF, Sahota DS, Cheung TH, et al: Gene expression pattern associated with radiotherapy sensitivity in cervical cancer. Cancer J 12: 189-193, 2006.

19. Helland A, Johnsen H, Frøyland C, et al: Radiation-induced effects on gene expression: an in vivo study on breast cancer. Radiother Oncol 80: 230-235, 2006.

20. Otomo T, Hishii M, Arai H, Sato K and Sasai K: Microarray analysis of temporal gene responses to ionizing radiation in two glioblastoma cell lines: up-regulation of DNA repair genes. J Radiat Res 45: 53-60, 2004.

21. Jeong J, Hong SJ, Ju YJ, et al: Temporal cDNA microarray analysis of gene expression in human hepatocellular carcinoma upon radiation exposure. Oncol Rep 15: 33-48, 2006.

22. Kumagai K, Nimura Y, Mizota A, et al: Arpclb gene is a candidate prediction marker for choroidal malignant melanomas sensitive to radiotherapy. Invest Ophthalmol Vis Sci 47: 2300-2304, 2006.

23. Xu QY, Gao Y, Liu Y, Yang WZ and Xu XY: Identification of differential gene expression profiles of radioresistant lung cancer cell line established by fractionated ionizing radiation in vitro. Chin Med J (Engl) 121: 1830-1837, 2008.

24. Lee YS, Oh JH, Yoon S, et al: Differential gene expression profiles of radioresistant non-small-cell lung cancer cell lines established by fractionated irradiation: tumor protein p53-inducible protein 3 confers sensitivity to ionizing radiation. Int J Radiat Oncol Biol Phys 77: 858-866, 2010.

25. Donato R: S100: a multigenic family of calcium-modulated proteins of the EF-hand type with intracellular and extracellular functional roles. Int J Biochem Cell Biol 33: 637-668, 2001.

26. Tarabykina S, Kriajevska M, Scott DJ, et al: Heterocomplex formation between metastasis-related protein S100A4 (Mts1) and S100A1 as revealed by the yeast two-hybrid system. FEBS Lett 475: 187-191, 2000.

27. Helfman DM, Kim EJ, Lukanidin E and Grigorian M: The metastasis associated protein S100A4: role in tumour progression and metastasis. Br J Cancer 92: 1955-1958, 2005.

28. Ikenaga N, Ohuchida K, Mizumoto K, et al: S100A4 mRNA is a diagnostic and prognostic marker in pancreatic carcinoma. J Gastrointest Surg 13: 1852-1858, 2009.

29. Boye K and Maelandsmo GM: S100A4 and metastasis: a small actor playing many roles. Am J Pathol 176: 528-535, 2010.

30. Mishra SK, Siddique HR and Saleem M: S100A4 calciumbinding protein is key player in tumor progression and metastasis: preclinical and clinical evidence. Cancer Metastasis Rev 31: 163-172, 2012.

31. El-Deiry WS: The role of p53 in chemosensitivity and radiosensitivity. Oncogene 22: 7486-7495, 2003. 
32. Bristow RG, Benchimol S and Hill RP: The p53 gene as a modifier of intrinsic radiosensitivity: implications for radiotherapy. Radiother Oncol 40: 197-223, 1996.

33. Li R, Sutphin PD, Schwartz D, et al: Mutant p53 protein expression interferes with p53-independent apoptotic pathways. Oncogene 16: 3269-3277, 1998.

34. Saintigny Y, Rouillard D, Chaput B, Soussi T and Lopez BS: Mutant p53 proteins stimulate spontaneous and radiation-induced intrachromosomal homologous recombination independently of the alteration of the transactivation activity and of the G1 checkpoint. Oncogene 18: 3553-3563, 1999.

35. Cadwell C and Zambetti GP: The effects of wild-type p53 tumor suppressor activity and mutant p53 gain-of-function on cell growth. Gene 277: 15-30, 2001.

36. Williams JR, Zhang Y, Zhou H, et al: A quantitative overview of radiosensitivity of human tumor cells across histological type and TP53 status. Int J Radiat Biol 84: 253-264, 2008.

37. Grigorian M, Andresen S, Tulchinsky E, et al: Tumor suppressor p53 protein is a new target for the metastasis-associated Mts1/S100A4 protein: functional consequences of their interaction. J Biol Chem 276: 22699-22708, 2001.
38. Frazier MW, He X, Wang J, Gu Z, Cleveland JL and Zambetti GP: Activation of c-myc gene expression by tumor-derived p53 mutants requires a discrete $\mathrm{C}$-terminal domain. Mol Cell Biol 18: 3735-3743, 1998

39. Ahmed KM and Li JJ: NF-кB-mediated adaptive resistance to ionizing radiation. Free Radic Biol Med 44: 1-13, 2008.

40. Dai Y, Lawrence TS and Xu L: Overcoming cancer therapy resistance by targeting inhibitors of apoptosis proteins and nuclear factor-kappa B. Am J Transl Res 1: 1-15, 2009.

41. $\mathrm{Li} \mathrm{F}$ and Sethi G: Targeting transcription factor NF- $\kappa$ B to overcome chemoresistance and radioresistance in cancer therapy. Biochim Biophys Acta 1805: 167-180, 2010.

42. Boye K, Grotterød I, Aasheim HC, Hovig E and Maelandsmo GM: Activation of NF- $\mathrm{BB}$ by extracellular S100A4: analysis of signal transduction mechanisms and identification of target genes. Int $\mathrm{J}$ Cancer 123: 1301-1310, 2008. 